\title{
How can I start? How to go forward after the trauma of cancer diagnosis
}

\author{
Judith Edwards* \\ Cansurviving, UK
}

\begin{abstract}
For any person, a cancer diagnosis is a shock and a trauma. Any shock stops thinking and for a time the shock of diagnosis can paralyse a person's capacity to carry on in a constructive way with the next part of their life. This short talk given at the International Women's Health and Breast Cancer Conference in the UK in October 2016, described initiatives based on the international group built site www.cansurviving.com discussed ways of proceeding after diagnosis, and explored complementary and alternative treatments to aid the healing process.
\end{abstract}

\section{Introduction}

Why me? may be a question. And help! 'what can I do now? For the understanding of those who have built this site, starting from the Site |Founder Judith Edwards onwards, both the development of cancer and the kick-starting of the healing process is a multi-factorial issue, and there are no cast- iron guarantees offered in any route, orthodox or alternative. What is vital is for a renewed sense of self-empowerment to grow, despite inevitable setbacks, in order for body, mind and spirit to be parts of the healing process. As a psychoanalytic psychotherapist for over thirty years, I have found the processes of being contained, and thus being able to engender one's own sense of hope and empowerment, to be constructive and indeed vital for change and growth to take place. The talk opened doors to different ways of thinking which can be used together to aid both physical and mental health. We link with other sites promoting cancer healing in order to give our members the widest view possible, but from the vantage point of one site to which they may return and browse freely, again and again, over the years.

\section{Survivorship and sailing on}

This is the big question which confronts anyone given a potentially life- threatening diagnosis. There is of course the wish to survive, and then the accompanying thought: what is survivorship for? The logo for the site www.cansurviving.com is a little boat, with a compass superimposed on the image, and a background of a calm sea. This international group built site which now has nearly 500 members sees itself as existing as a sort of chandlery by the waterside, so that each person may load up their own little boat with what they need to move on. Recently someone said the site had been recommended to him in Australia by some colleagues in the USA who said it was 'the best site on the web for healing cancer'. Since there are over $9 \mathrm{~m}$ of them (to date) that's quite an accolade. We work as a team, majoring on this question of the purpose of survivorship, which we consider to be a new state of mind where one gives back to others. For any person, a cancer diagnosis is a shock and a trauma. Any shock stops thinking and for a time the shock of diagnosis can paralyse a person's capacity to carry on in a constructive way with the next part of their life. On this international group built site we discuss ways of proceeding and explore complementary and alternative treatments to aid the healing process.

\section{So what is Cancer?}

There are over 200 different types of cancer, and they are formed when abnormal cells start dividing uncontrollably, in an oxygendepleted environment. We all have Cancer cells in our bodies every day, but they die off, in a process called cell apoptosis (maybe somewhat similar to SF's death instinct) - but when something stops this happening, then they start to accumulate, and trouble begins in the body. If you look on the Web currently there are over $563 \mathrm{~m}$ posts about Cancer, and over 9M as I said previously for Curing Cancer- it's a hot topic. So that is Cancer the physical disease, and we need to look at root causes to find out why it develops- is it environmentally caused, or is it to do with genes, or stress and conflict, or a combination of these, or just luck? The human desire for straightforward causation is strong- but rarely the end of the story. And are we going to stop at curing symptoms, which classic orthodox medicine still does, or are we going to find real solutions for treating it by looking beyond man-made drugs to the very basis of why cancer occurs, thinking of disturbances in metabolic functions? And in terms of women and breast cancer, there's a problem here. Progesterone helps to prevent breast cancer, whereas oestrogen is known to promote it. Oestrogen dominance is at the very heart of what promotes breast cancer. Oestrogen and progesterone work in harmony with one another. They oppose one another to achieve balance. However, if a woman has too much oestrogen and too little progesterone, the body no longer functions in perfect homeostasis, and the cancer risk is elevated. When the opposing force of progesterone is increased, the toxic effect of oestrogen is decreased. Progesterone turns on genes that can prevent breast cancer from occurring and reduces the size of existing tumors. But it can't do that if there is excess oestrogen. So already, it's complicated, people get dazed and amazed by the 'facts'

Correspondence to: Dr. Judith Edwards, Cansurviving, 36 Ansleigh Place, London W11 4BW, UK, Tel: 0044 (0)207 727 8759, E-mail: judith@judithedwards.co.uk

Key words: cancer, healing cancer, survivorship, group process, complementary and alternative treatments

Received: November 10, 2016; Accepted: December 02, 2016; Published: December 07, 2016 
and stop thinking for themselves.

Then there is the psychological fear attached to the word cancer, the 'Emperor of All Maladies' as the Indian author Mukherji (2010) [1] has called it in his ground-breaking book about the subject (reviewed on the site)- now it is predicted that one in 2 people will develop some form of cancer, so everyone is on red alert and the word strikes terror into people's hearts.

We need as patients to stop making the cancer and try to get to the cause- this is a multi-factorial issue, a holistic process: there has been a multi-system failure. We need to step back and look at the 'perfect storm' which has occurred, involving body, mind and spirit. This site addresses the whole system, but from a perspective that preliminary lay people with terror in their hearts can begin to understand. Mindset is key here - if you think it's possible, it's possible. Conceive, believe, achieve- and stay curious!

\section{Questions}

I was recently asked to appear on Iranian TV to talk about the site, and they asked me some relevant questions, the first of which was what do you do if you've just received a diagnosis?

The advice we give on the site is that you wait- you try not to panic, don't be rushed into agreeing to anything till you've carefully considered the pros and cons: there's a useful list of questions on the site to ask your oncologist before you find yourself bounced into treatment. Empower yourself with as much knowledge as you canand try not to fall into the urgency trap.

Their second question was about getting a second opinion. My reply to this was that it is vital to consult an alternative practitioner too and again there's a list of helpful questions to ask on the site. It is important to be proactive and to do your own research.

Their last question was a poignant one: how do you get through this tough time? I told them a story which I recount here.

When I first was diagnosed with cancer at the beginning of January 2012 I dreamed of driving in my car into a huge black cloud. I could see nothing. But I could see that further along - how much further along? The cloud turned into thin fog, then who knew what came next?

Yes, a storm was brewing. I can now look back, and I really resonated with something Haruki Murakami said in his novel Kafka on the Shore [2].

"Once the storm is over you won't remember how you made it through, how you managed to survive. You won't even be sure, in fact, whether the storm is really over. But one thing is certain. When you come out of the storm you won't be the same person who walked in. That's what this storm's all about"

Now this site exists, nearly five years later, for others who walk into the storm. Take heed of your dreams, we advise, and give back when you emerge from the black clouds.

\section{Site forums}

So on the site we have forums which have evolved as the site has evolved, according to need. There is of course a large forum dealing with Diet and the Body, where we are concentrating on the Ph Factorthe potential hydrogen factor- keeping the blood alkaline so that cancer cells cannot thrive- they thrive where there is no oxygen, in an acid environment. Oxygen keeps Cancer at bay, as Otto Warburg the Nobel
Prize Winner said in 1931- oxygen is the enemy of the Cancer cell- This forum has recipes and tips from all our members, (for instance green juices for those undergoing chemotherapy from one of our Brazilian members) plus recommendations about getting a healing team around you: my own preference was for a team of three, an acupuncturist, a homoeopath and a naturopath, and I talked about this on the radio programme we did in 2015. Here is also a link to this on the site. Related to this are the Restaurants that are Vegan Friendly forum- we have posts from around the world from Beijing to Paris to Nova Scotia. The Research section keeps us up to date with what is happening in relevant fields and is headed by a leading researcher from 'What the Doctors Don't Tell You'. There is some research recently published in the Lancet for instance about the deleterious effect of much chemotherapy on the patient. Then there is a Library section with reviews of helpful books, (not by the person who wrote them!), a Mind and Spirit Forum on which members offer their different ideas about meditation and mindfulness (now 'scientifically proved' to be brain-changing), on being a Quaker, dancing, laughing, exercising, music and poetry. There's a Creativity after Diagnosis Forum which can be an inspiration for people- both so called 'famous' people and just ordinary people like you and me can experience this. And quite a late arrival was the How do I start? Forum (hence the title for this paper), for those who feel shocked by the ice-cold wave that hits them with diagnosis, and want some help to move forward. There's also a Personal Stories forum and a How Can I help section too. There's a Let it Be Forum which is about something which can beset all cancer patients (and indeed all people!) - depression. More of that later.

\section{Rebuilding}

Did you know that your body rebuilds itself in less than a year? 98\% of your body rebuilds itself in less that 365 days, the remaining $2 \%$ takes another year...Since every cell in the body dies and is replaced by new cells, you're now on the way, we say, to building a healthier version of yourself- let's just take a look at some of the replacement going on... Your stomach lining takes 5 days to change totally, your skin replaces itself in a month, your liver rebuilds itself in 6 weeks, DNA is renewed every 2 moths- bones are rebuilt in 3 months- a whole new skeleton! Blood takes 4 months- as I found when I went to the naturopath for blood micro-analysis as is described in the Naturopathy Forum. Your brain takes a year to rebuild. Making new neural connections in the brain is, we feel, vital to this whole enterprise.

The internet can be the source of so much information, but one can swim around in confusion too, as many people do, stricken with fear after cancer diagnosis. This website gives people a starting point to which all can contribute on a number of subjects all related to what we're trying to do : that is to change-it is a good thought that we are working on a new model of ourselves.

\section{Depression}

All this can be hard work, and depression may be an inevitable part of it.

I was talking to my dear friend Al Alvarez (who knows a thing or two about depression: he is the author of The Savage God 2002 new edition) [3] about this new forum when it was set up, and about how each day can seem a new drag on an already dragging spirit. $\mathrm{He}$ quoted a poem by A. E. Housman [4] word for word, 'Yonder see the morning blink'; which might resonate with people on the down days. Yonder see the morning blink/The sun is up, and up must I,/ Towash and dressand eatanddrink/Andlookat thingsand talkand think/ 
And work, and God knows why.

Each day there may be a bit of this, and then the spirit rises, maybe not. Just try and recognise this feeling as one of many, we advise, let it rise, let it break like a wave, let it dissipate. Easy words to say and hard sometimes to see this through, but we can all support each other and talking is vital. As Atul Gawande said in his 2014 Reith lecture The Future of Medicine (also on the site) [5] 'If talking was a drug, it would cost millions of pounds'...

The patient as well as both family and friends may be particularly struck by dark feelings after a cancer diagnosis. While this hopefully will not forever be 'the new normal' it may always be around somewhere, and it is probably easier and more efficacious to accept this new feeling rather than try to 'rise above it': you might avoid fewer big crashes by so doing. In essence, this is about how to feel sad rather than be sad. Wake up, be aware of it, move it along in its own time... just do your best.

Laurie Anderson (who sang 'Oh Superman' in the 70s and is the widow of Lou Reed the rock star) was talking recently about her new film Heart of a Dog. She said her Tibetan master had said it was important to Allow the feeling but not become it, as we're saying here. Tricky may be but doable with practice.

\section{Will you or wont you?}

And then there's the elephant in the room: death. We're all going to die sometime, and so we have a forum on the site about death and dying, 'Will you or won't you?' to address this often unmentionable subject. It was Seamus Heaney who said to his wife just before he died 'noli timere' - don't be scared. In a sense this sums up what we feel and try to promote on the site, that life is all about trying not to be scared- not being scared into paralysis, lying back and gasping 'heal me'- but finding ways forward together, in a group- not for nothing was this site recently called as I have already said 'the best site on the web for healing cancer', because it bangs no one person's drum, sells no one person's point of view or book or video, but surveys the field so that members can browse and find their own way. Just as no two psychoanalytic encounters are the same, so no two paths forward are the same for people after diagnosis: the vital thing is to walk on (and that's great exercise too!) 'Those who think they have no time for exercise will sooner or later have to find time for illness as the old saying goes. And as a member from Colombia said when she posted a video about a young Vietnamese veteran who learned to run from being flat on his back: 'never, ever give up'.

So what we're talking about on the site is putting the pieces back together after the shattering effect of a cancer diagnosis. Our evergrowing community of searchers all help one another. We advise our members to try and avoid the nay-sayers- they are always with us! Amos $\mathrm{Oz}$ the Israeli novelist recently said: 'The accusation of betrayal is often the reward a person receives simply for the act of changing. If they change their mind they are accused of betraying the cause, even if they're simply finding a new way to serve the cause better' (2016) [6]. Changing is at the heart of our endeavour here.

More people die of ignorance than cancer- 'for lack of information the people may perish' as the Scriptures said (Hosea)- now there are many on the site not of the Old Testament persuasion but the maxim holds true. And as the philosopher Schopenhauer said in the $19^{\text {th }}$ century 'All truth passes through three stages: First it is ridiculed, Second it is violently opposed, Third it is accepted as self- evident' Hopefully we are get nearer that end-point as time goes by. People can browse around the site, like a bookshop- they don't have to register first though we hope they may become members later. We're all free to come back again and again, to think about everything from diet to dancing, laughing to love, juicing to joy.

An individual does not get cancer- a family does. And here's what we try to do, in a nutshell: We all need mentors, and we can co-mentor one another on this site. There's only so much we can individually master, so the wise teacher is always a student of something. The most effective way to keep your brain young and sharp is to continue learning. Having friends is important, having buddies you can turn to is vital. We are all here for one another!

Mastering the basics is the most important part of any practice. Then you can find yourself flooded (in a good way!) with fresh new ideas and strategies that you wouldn't have thought of along the way, if you'd done this on your own. And of course helping people on their respective paths feels pretty good too!

\section{Conclusion}

It was the novelist Maya Angelou who said that she had learned that while people may forget what you say, they will never forget how you made them feel. We have had a lot of feedback from people feeling very much better when they have a sense of being more in charge of their own futures.

And as I and my professional colleagues have found too over many years, mind set is key.

Herman Melville the nineteenth century novelist talked about the 'thousand fibres that connect us to our fellow men.' We cannot live only for ourselves he insisted.

This useful bit of wisdom involves community, which is an important, and often overlooked human need. Our community of searchers grows- and the multi-factorial approach is one which embraces everything rather than shouting out 'this way is best!'. 'Let's not fight' is another of our watchwords- fighting takes energy away from the important task of changing. To quote $\mathrm{Amoz} \mathrm{Oz}$ again: "what some people may call treason is 'simply the courage to be ahead of your time" Courage is promoted by working in a group, and our group is growing [6].

Just over 18 months ago a singer-songwriter wrote us our very own song called 'Take a Look Outside the Box'--- http://www.jpkalliomusic. com/outside-box/ (also on the site). That is a good way to begin and also to end this account. We need to keep on thinking, not in competition with anyone, but in cooperation, in order to help women and men and children too who receive a diagnosis, go on to live their lives fully.

\section{References}

1. Mukerjhee S (2010) The Emperor of all Maladies: A biography of Cancer, New York, Scribner.

2. Murakami H (2005) Kafka on the Shore, New York, Vintage books

3. Alvarez Al (2002) The Savage God: A Study of Suicide, London and New York, Bloomsbury.

4. Housman AE (1967) Collected Poems, London, Jonathan Cape.

5. Gawande A (2014) The Future of medicine, BBC Reith Lectures.

6. Oz Amos (2016) Guardian newspaper interview, October 2016. 
Edwards J (2016) How can I start? How to go forward after the trauma of cancer diagnosis

Copyright: C2016 Edwards J. This is an open-access article distributed under the terms of the Creative Commons Attribution License, which permits unrestricted use, distribution, and reproduction in any medium, provided the original author and source are credited. 